Tomasz Pirowski ${ }^{1}$

ORCID: 0000-0003-0095-0316

Katarzyna Berka²

ORCID: 0000-0002-0271-3560

\title{
ANALYSIS OF LAND USE AND LAND COVER MAPS SUITABILITY FOR ESTIMATING POPULATION DENSITY IN URBAN AREAS - EXCLUSION OF THE EQUIFINALITY PHENOMENON ON POPULATION MAPS DEVELOPED FROM CLC, UA AND OBIA DATA ${ }^{1}$
}

\author{
${ }^{1}$ AGH University of Science and Technology \\ ${ }^{2}$ APR Services, Barnet Herts EN5 4DL, United Kingdom
}

Keywords: population data, dasymetric modeling, LULC, photointerpretation, equifinality phenomenon

\begin{abstract}
The series of articles contains a comparison of the possibilities of using for dasymetric estimation of population distribution of spatial information about buildings. The buildings come from three sources characterized by different spatial, thematic and temporal accuracy. These are data from Corine Land Cover (CLC) and Urban Atlas (UA) projects and the result of object classification (OBIA) of RapidEye data. The experiment was carried out in the area of Krakow. Statistical data from 141 city urban units (u. u.) were used.

In the first two parts of the cycle, population conversions based on CLC, UA, OBIA and OBIA in combination with UA were presented (Pirowski and Timek, 2018; Pirowski et al., 2018). In total, 12 maps of Kraków’s population were obtained. RMSE and MAPE mean errors were calculated as well as population density for each category of residential development. The results were discussed.

In the third part of the cycle, the obtained population maps were analyzed in detail, referring to the Bronowice district (the north-western area of the city) prepared especially by the population. The reference map has been made in high resolution. The methodology of its elaboration has been described in detail. Complementary use of orthophotomap from aerial photographs together with public databases (Geoportal, OpenStreetMap, GoogleStreetView) was presented. The proprietary MMAPE parameter has been proposed. The parameter analyzes the similarity of the reference map of Bronowice with the dasymetric maps. It allows you to statistically describe their credibility and exclude the phenomenon of equivalence.

As a result of the conducted research, an erroneous population distribution was detected for the variant OBIA, in which the weights were determined by minimizing the MAPE error. From the remaining experiments, the three best results were obtained by maps using information about urban development from Urban Atlas (MMAPE M0om $_{1}=19.3-22.1 \%$ ). Complementary use of OBIA and UA did not bring any synergy effect - the results were worse than for UA (21.6-24.3\%). High errors were noted for OBIA - it is only worth to notice a better result from the binary OBIA method (MMAPE $\mathrm{M}_{100 \mathrm{~m}}=22.8 \%$ ) than the result from the binary CLC method $\left(\mathrm{MMAPE}_{100 \mathrm{~m}}=24.3 \%\right)$.

At this stage of the research, UA data is recommended for the conversion of population. The object classification methods are not a reliable source of data on building types, and such information is necessary for the use of surface-by-weight methods. The use of OBIA is possible only in the binary method and gives results similar to the use of data from CLC.

In the fourth part, it is planned to verify the population maps using the Central Statistical Offic (CSO) kilometer network for the whole of Poland, which was made available in 2017. On the basis of multivariate tests and two-stage verification, the authors plan to provide the advantages and disadvantages of the described methods of population conversion and to develop a ranking of the obtained Krakow population maps.
\end{abstract}

1 The article has been prepared within the scope of the research subsidy of the Ministry of Science and Higher Education for AGH UST, no. 16.16.150.545 


\title{
ANALIZA PRZYDATNOŚCI MAP POKRYCIA I UŻYTKOWANIA TERENU DO SZACOWANIA LICZBY LUDNOŚCI OBSZARÓW MIEJSKICH - WYKLUCZENIE ZJAWISKA EKWIFINALNOŚCI NA MAPACH ZALUDNIENIA OPRACOWANYCH Z DANYCH CLC, UA I OBIA
}

Słowa kluczowe: dane demograficzne, modelowanie dazymetryczne, fotointerpretacja, ekwifinalność

\begin{abstract}
Abstrakt
Cykl artykułów zawiera porównanie możliwości wykorzystania do dazymetrycznego szacowania rozmieszczenia ludności informacji przestrzennej o zabudowie z trzech źródeł, charakteryzujących się różną dokładnością przestrzenną, tematyczną i czasową: dane z projektów Corine Land Cover (CLC) i Urban Atlas (UA) oraz klasyfikacji obiektowej (OBIA) danych RapidEye. Eksperyment przeprowadzono na obszarze Krakowa, wykorzystując dane statystyczne ze 141 jednostek urbanistycznych miasta.

W pierwszych dwóch częściach cyklu zaprezentowano przeliczanie populacji w oparciu o CLC, UA (Pirowski i Timek, 2018) oraz OBIA, w tym jej skorygowany wynik poprzez połączenie z UA (Pirowski i in., 2018). Łącznie uzyskano 12 map zaludnienia Krakowa. Poddano dyskusji obliczone błędy średnie RMSE i MAPE oraz wagi zagęszczenia ludności dla każdej kategorii zabudowy mieszkalnej.

W trzeciej części cyklu uzyskane wyniki poddane zostały szczegółowej analizie dzięki specjalnie przygotowanej przez autorów, wysokorozdzielczej referencyjnej mapie ludności dzielnicy Bronowice (północno-zachodni obszar miasta). Szczegółowo opisano przyjętą metodykę jej opracowania, w tym komplementarne wykorzystanie interpretacji ortofotomapy ze zdjęć lotniczych oraz ogólnodostępnych baz danych (Geoportal, OpenStreetMap, GoogleStreetView). Zaproponowano autorski parametr MMAPE, analizujący podobieństwo mapy referencyjnej Bronowic z mapami dazymetrycznymi, pozwalający statystycznie opisać ich wiarygodność i wykluczyć zjawisko ekwifinalności.

W wyniku przeprowadzonych badań wykryto błędny rozkład ludności dla wariantu opartego o klasyfikację obiektową z ustalaniem wag na drodze minimalizacji błędu MAPE. Spośród pozostałych eksperymentów trzy najlepsze wyniki uzyskały mapy wykorzystujące informacje o zabudowie z Urban Atlas (MMAPE M00m $_{10}$ 19,3-22,1\%). Komplementarne wykorzystanie OBIA i UA nie przyniosło efektu synergii - wyniki są gorsze niż dla UA (21,6-24,3\%). Wysokie błędy odnotowano dla OBIA - warto jedynie odnotować lepszy wynik dla metody binarnej OBIA $\left(\mathrm{MMAPE}_{100 \mathrm{~m}}=22,8 \%\right)$ niż dla metody binarnej $\left.\mathrm{CLC}_{(\mathrm{MMAPE}} \mathrm{M}_{100 \mathrm{~m}}=24,3 \%\right)$.

Na tym etapie badań rekomenduje się do przeliczania ludności stosować dane UA. Metody klasyfikacji obiektowej nie są wiarygodnym źródłem danych o rodzajach zabudowy, niezbędnym dla metod powierzchniowo-wagowych. Stosowanie OBIA jest możliwe w metodzie binarnej i daje rezultaty zbliżone do korzystania z CLC.

W czwartej części planuje się weryfikację map zaludnienia wykorzystując siatkę kilometrową GUS, udostępnioną przez urząd w 2017 roku, dla całej Polski. Na bazie wielowariantowych testów i dwuetapowej weryfikacji autorzy planują podać ograniczenia proponowanej metody przeliczania ludności oraz opracować ranking map.
\end{abstract}

\section{INTRODUCTION}

As a result of the widespread support of decisions taking into account the spatial context, reliable mapping of the detailed distribution of population has become essential. It is the basic information for demographic analysis - tracking changes and their forecasting in a spatial context. Distribution of people is also crucial for many related fields: in modeling and space management, in business (geomarketing, investment location, competitive advantage), in administration (planning of population service, communication), in responding to crises (floods, fires, contamination) environment).

The very problem of the presentation of the population distribution has been accompanied by cartography for many years, starting with dot methods, isolines, or simple cartograms (Ratajski, 1989). Due to the dynamic development of data acquisition, the improvement of their spatial resolution and news, mainly due to the development of remote measurement techniques, traditional methods of obtaining data on the population have become insufficient. With the spread of geographic information systems (GIS), the dasymetric cartogram became a more popular and much more accurate way of presenting the distribution of the population. In contrast to the simple proper cartogram, the reference areas are not arbitrarily imposed in the form of administrative or census units, but result from the spatial distribution of the phenomenon (Pirowski and Drzewiecki, 2012).

The increase in the availability of data on land cover, primarily due to the development of remote sensing techniques, allows estimating the population distribu- 
tion in higher resolution than the statistical data from census units originally collected and made available. A review or comparison of methods binding data on land cover with the population can be found, among others in the works of Wu et al. (2005), Zandbergen and Ignizio (2010) and in the International Journal of Remote Sensing special edition devoted to this issue (Wang and $\mathrm{Wu}, 2010$ ). The population mapping methodology is still being developed, along with the increase in data conversion capacity, the increasing availability of high resolution satellite data and laser scanning, building data bases on buildings. The areas of urban agglomerations are frequently mapped (Maantay et al., 2007, Kunze and Hecht, 2015, Tomás et al., 2016, Pavia and Cantarino, 2017, Pirowski and Bartos, 2018).

Following the content of the publication, it can be noticed that their authors stage secondary verification of developed population maps, focusing mainly on the correct identification of limiting variables (impermeable zones, built-up areas, residential buildings) and / or variable relationships (type of building and its functions, density of buildings) and street networks, building heights, night-time intensities, etc.). The indicators used for the assessment of this process are most often the correlation values or the degree of minimization of deviations. These are parameters occurring at the stage of determining weights in surface-by-weight methods, where it is necessary to estimate the correct differences in population density attributed to individual development areas (Gallego and Peedell, 2001; Bielecka, 2005; Pirowski and Bartos, 2018). Another approach validating the method is the cancellation of recalculated population maps, after their re-aggregation, to the original census units. Detection of differences at this level is the basis for the evaluation of the method - for example, Tomás et al. (2016), Całka et al. (2016). The lists presented by the authors indicate average errors in units below $10 \%$. Often, recalculated population maps, where the principle is to bring the volume of census units into statistical data, are not subject to quantitative verification, and discussion takes place at the level of qualitative interpretation of results. In such cases, the authors usually analyze in detail representative small fragments of the analysis area, checking whether the resulting diversity of population distribution is within the real ranges that can occur (Xie, 2006, Strofan, 2008, Pirowski and Drzewiecki, 2012). An extended analysis of the reliability of the results can be found with the authors' multivariate tests (Zandberg and Ignizio, 2010) or paying attention to the uncertainty of modeling population distribution (Nagle et al., 2014). The reason for using limited methods of assessing prediction models of population mapping is the lack of independent, reference data and the method of livelihood is difficult to apply due to the limited number of input census data. The presented article attempts to valorize different population maps through a specially prepared, reference map of population distribution. This map was developed on a photointerpretation route, with the support of additional databases. Due to the time-consuming nature of the work, the area of study was limited to a fragment representative for the entire city.

Population maps, valorised, were developed on the basis of three data sources on land use and land cover (LULC - Land Use and Land Cover). These are two maps from the pan-European projects: Corine Land Cover (CLC) and Urban Atlas (UA) and the built-up area map obtained from object classification (OBIA) of the RapidEye image. In each case, population conversion was based on the dasymetric method, treating building zones as limiting variables, and the division into building types as changing relations. Proportions in population density for particular building classes were obtained by iterative minimization of errors in the original census units. Details of the methodology are included in the two previous publications of the series (Pirowski and Timek, 2018; Pirowski et al., 2018), in short they consist of:

- take into account in the first stage of analyzes only the global population (total, from all census units, in this case it is the population of Krakow, being the sum of population from individual 141 urban units (u. u.) of the city);

- searching for appropriate weights for individual building categories, so that in each of the census units (in Polish) get the smallest possible deviations in relation to the actual (from statistical data) population; the minimization of deviations was based on two parameters: RMSE and MAPE;

- final population maps have been elaborated eliminating deviations in $\mathrm{j}$., that is, leading to the compliance of their population volume with statistical data, by applying an appropriate correction factor for absolute values of population density; this procedure maintains the calculated proportions of weights between individual building categories. 
The implementation of these stages allowed for the development of a total of 12 variants of Krakow's population maps, i.e. three maps from the CLC, three maps from the UA, three maps from OBIA and three maps from OBIA + UA. Each of the subgroups formed variants: binary, surface-weight with minimization of RMSE and surface-weight with minimization of MAPE. At this stage, the measure of the correctness of the selection of weights, and indirectly the assessment of the variant of population distribution, were the deviations for u. u. and RMSE / MAPE errors.

The main research problem undertaken in this third part of the cycle is to verify the previously developed population maps. There is a potential possibility that the dazymetrically obtained population distribution is not correct, although in aggregate spatial units, for example in urban units, it seems to be correct. This phenomenon is called the ekwifinalności. It can occur at the stage of the binary method, with incorrect spatial representation of building zones. In the case of the surface-weight method, additionally subjected to subjectivism in the selection of weights for particular building categories, the probability of this phenomenon increases. In order to indicate which of the tested results does not have such a defect, it is necessary to have reliable reference data with a detailed - in terms of space - population distribution. For this purpose, a reference map of the Bronowice district prepared on the basis of aerial orthophotos was prepared. The development of this type of reference data, the ways of its use for the assessment of population maps and the related discussion is new compared to the previously published methodological experience and the validation of the dasymetric population conversion.

\section{DEVELOPMENT OF HIGH-RESOLUTION REFERENCE DATA}

For the analyzes verifying the high level of detail, the population distribution developed from the CLC / UA / classification maps, the Bronowice district was selected, which is characterized by a large variety of land

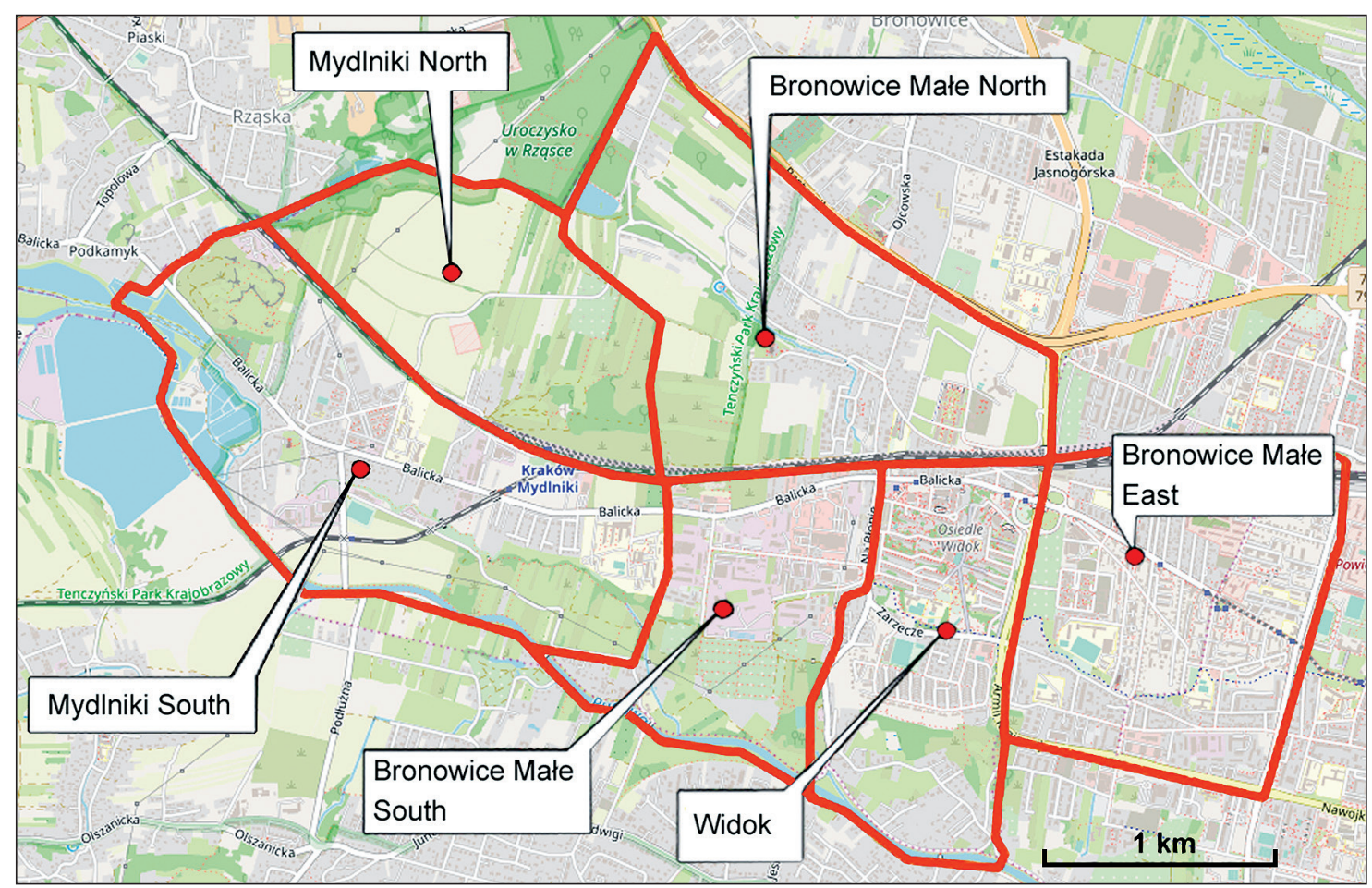

Fig. 1. The study area (Bronowice district) with a division into urban units (cartographic foundation - source: (C) OpenStreetMap contributors, www.openstreetmap.org/copyright).

Rys. 1. Obszar analizy - dzielnica Bronowice, z podziałem na jednostki urbanistyczne (podkład mapowy - źródło: (C) OpenStreetMap contributors, www.openstreetmap.org/copyright) 
cover and can be a sample representative for the whole city (Kruszyńska et al., 2001) (Fig. 1)

The first stage of the works was to obtain a map of residential places at a higher level than contact details, through spatial localization and appropriate categorization of single-family buildings and staircases of multi-dwelling buildings (hereinafter referred to as ,residential points") (Table 1). The division into: single-family houses (designation „K1”), tenement houses (K2), cages of very low blocks ( $2-3$ floors, ,new construction”, Figs 2a, 2b) (K3), low (4-5 floors) (K4), high-rise buildings (K5). The photointerpretation was made on ortho-
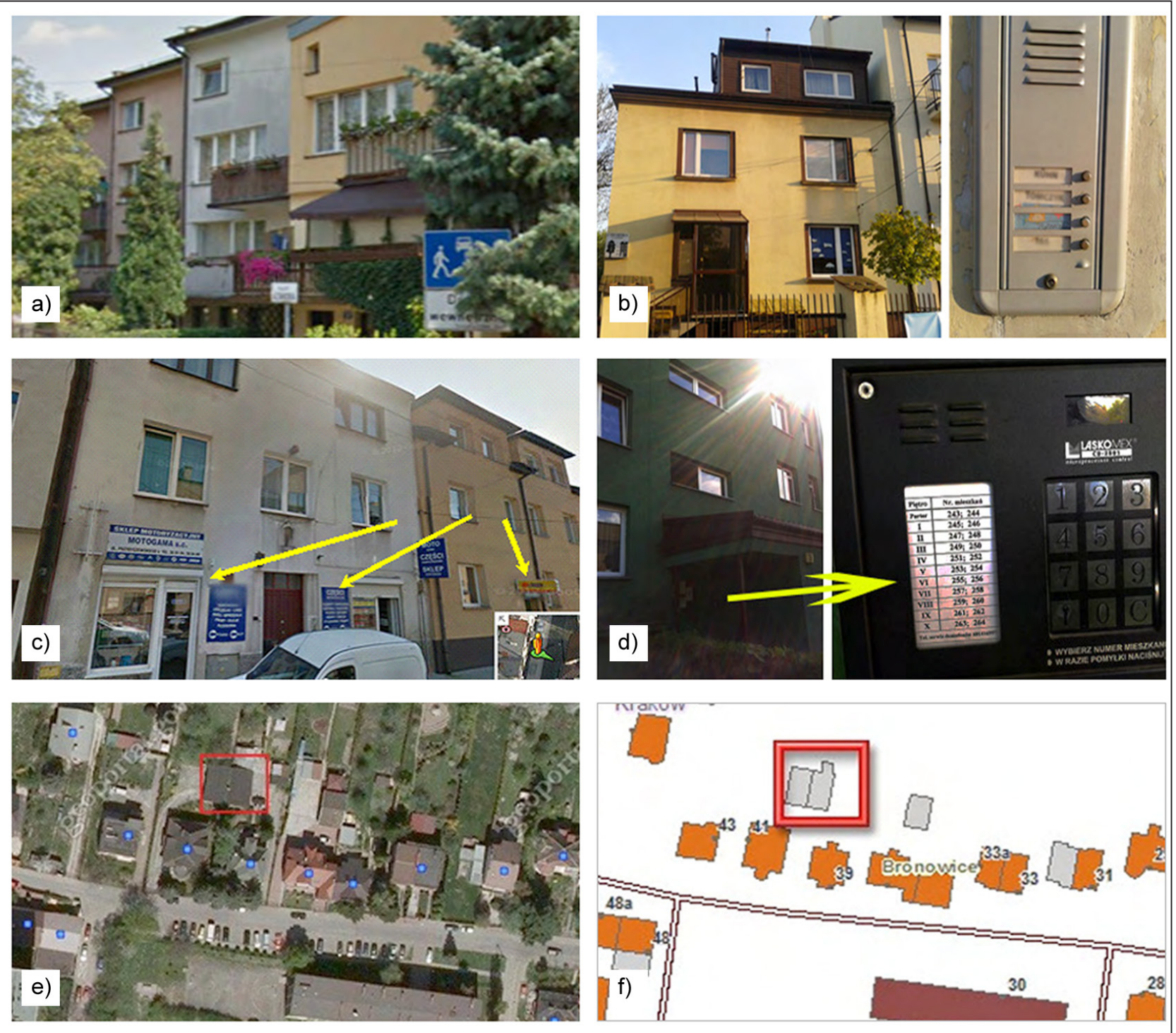

Fig. 2. Field interpretation of photointepretation works: a, b) example of „new construction” - cages of 2-3 storey blocks, c) Google Street View analysis - identification of non-residential surfaces; d) field visits - analysis of the number of inhabitants via the intercom directory; e, f) using BDOT to verify the correctness of the orthophotomap interpretation - exclusion of non-residential objects.

Rys. 2. Przykład wsparcia prac fotointepretacyjnych: a, b) przykład „,nowego budownictwa” - klatki bloków 2-3 piętrowych, c) analiza Google Street View - identyfikacja powierzchni niemieszkalnych; d) wizyty terenowe - analiza liczby mieszkańców poprzez spis domofonowy; e, f) wykorzystanie BDOT do weryfikacji poprawności interpretacji ortofotomapy - wykluczenie obiektów niemieszkalnych 
Tab. 1. Bronowice district. Statistical data from 2009 and results of photointerpretation analysis

Tab. 1. Dzielnica Bronowice. Dane statystyczne z 2009 roku oraz wyniki analizy fotointerpretacyjnej

\begin{tabular}{|c|c|c|c|c|c|c|c|c|c|c|c|c|c|c|}
\hline & \multirow{3}{*}{$\begin{array}{c}\text { CSO } \\
\text { popu- } \\
\text { lation }\end{array} \mid$} & \multicolumn{5}{|c|}{ number of residential points } & \multicolumn{3}{|c|}{ estimated population } & \multicolumn{5}{|c|}{ number of people per resid. point } \\
\hline & & \multirow{2}{*}{ K1 } & \multirow{2}{*}{$\mathbf{K} 2$} & \multirow{2}{*}{ K3 } & \multirow[b]{2}{*}{ К4 } & \multirow{2}{*}{ K5 } & number & PE[\%] & $\mathbf{K}(\mathbf{u u})$ & K1 & K2 & $\mathbf{K 3}$ & K4 & K5 \\
\hline & & & & & & & \multicolumn{3}{|c|}{ boundary conditions $\rightarrow$} & $2-4$ & 6-12 & $12-18$ & 24-36 & $60-90$ \\
\hline Bronowice & 23306 & 1788 & 37 & 168 & 299 & 102 & 24093,4 & 3,38 & 0,967 & 3,10 & 6,00 & 12,00 & 29,01 & 74,94 \\
\hline Bron. I & 11365 & 535 & 37 & 88 & 193 & 46 & 11701,0 & 5,43 & 0,949 & 2,94 & 5,69 & 11,38 & 27,52 & 71,09 \\
\hline Widok & 8204 & 454 & t & 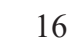 & 83 & 56 & (2) & $-0,02$ & 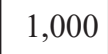 & 3,10 & 6,00 & 12,00 & 29,02 & 74,96 \\
\hline Bron. & 1225 & 346 & 0 & 36 & 0 & 0 & 3,2 & 22,71 & 0,815 & 2,52 & 4,89 & 9,78 & 23,64 & 61,07 \\
\hline Bro & 458 & 14 & 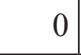 & 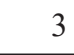 & 3 & 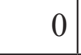 & 2 & $-23,11$ & 1 & 4,03 & 0 & 15,61 & 74 & 97,47 \\
\hline Mydlniki Pd & 1967 & 351 & 0 & 25 & 20 & 0 & 1967,0 & 0,00 & 1,000 & 3,10 & 6,00 & 12,00 & 29,01 & 74,94 \\
\hline Mydlniki Płn. & 87 & 28 & 0 & 0 & 0 & 0 & 86,7 & $-0,36$ & 1,004 & 3,11 & 6,02 & 12,04 & 29,12 & 75,21 \\
\hline
\end{tabular}

photomaps developed from digital aerial photographs, on a scale of 1: 10000, made available on the Geoportal. Support for interpretation work was parallel use of publicly available portals and services such as Google Maps, Google Street View (similar approach used by Kang et al., 2018), which allowed for correct identification of multi-dwelling buildings (in particular, the distinction between tenement houses and low and medium blocks), as well as detecting the presence of non-residential surfaces (offices, shops, services) in them (Fig. 2c).

Open Street Map data (modeled here on the Kunze and Hecht ideas (2015)) and the national database on buildings (BDOT) enabled the detection of non-residential objects such as garages, workshops or stores
(Fig. 2e, 2f). In particularly questionable places, field visits were made, which were photographed (Fig. 2b, 2d).

In the second stage of the work, categorized residential points were linked to population data from urban units, using the experience published by Pirowski and Drzewiecki (2012). The MAPE minimization algorithm (RMSE was rejected due to the large population population span for individual units), fixed proportions for Bronowice, proportions of population density for the adopted five building categories. Due to the fact that low (even negative) values were obtained for tenements and blocks of flats, the limit numbers for each category were adopted. Values were calculated using the iterative method, the spreadsheet solver module (MAPE =
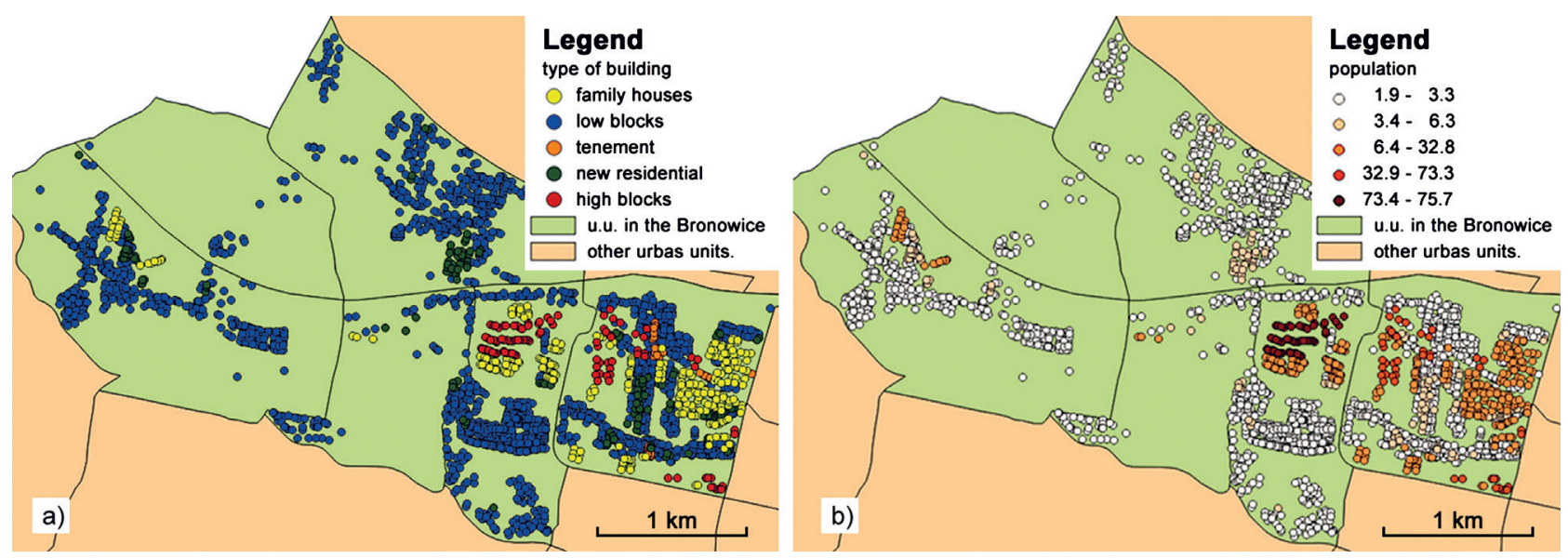

Fig. 3. Bronowice district: a) result of interpretation; b) population distribution Rys. 3. Dzielnica Bronowice: a) wynik interpretacji; b) rozkład populacji 
$8.6 \%$ ). Then, the global population in a given plane was adjusted. according to the factor K(uu) (Table 1).

The final stage of the works was assigning the estimated number of inhabitants to dwelling points (Fig. 3a) (Fig. 3b). This map was the basis for generating raster maps of the population of various resolutions, as a reference material for determining the accuracy of CLC, UA and OBIA based products.

\section{VERIFICATION OF DASYMETRIC MAPS USING THE DEVELOPED POPULATION MAP OF BRONOWICE}

The mapping of residential points in the interpretation method results in assigning high point values to the population, while the majority of the area is deprived of population. In turn for maps created with LULC, the characteristic feature is the occurrence of continuous building areas with relatively low population concentration. The use of such different methods of mapping (logical due to the genesis of maps and the degree of their generalization) causes difficulties in the selection of an appropriate statistical measure. Indicator allowing to determine the reliability of products with lower accuracy in relation to the detailed reference map. After numerous tests, a solution was chosen consisting in a gradual degradation of both sets of data (reference map and controlled maps) and thus moving from the population distribution map (population volume on a given cell) to an aggregated map of the local population density in the surrounding of the given cell (population volume in a given radius around the central cell). With this approach, in the case of larger spatial units, properly devel- oped variants of dasymetric maps will show low errors. The problem of the local lack of precision of the spatial distribution of the population in the form of separate residential points, irrelevant from the point of view of the practical use of population maps, will be removed. For methods in which there is the equifinality phenomenon, i.e. an incorrect distribution of population, the values of deviations will not fall significantly, or even increase.

To achieve this goal, the interpretive map was converted into a 5-mm raster format, similar to the previous ones for CLC and UA maps. Then, through the function of the convolution, the local population was counted using the averaging filters with the window size: $3 \times 3,5 \times 5,11 \times 11,21 \times 21,51 \times 51,101 \times 101$, which approximately corresponds to the following areas: $10 \times 10 \mathrm{~m}, 25 \times 25 \mathrm{~m}, 50 \times 50 \mathrm{~m}, 100 \times 100 \mathrm{~m}, 250 \times 250 \mathrm{~m}$, $500 \times 500 \mathrm{~m}$ (Fig. 4).

Next, the differences in population density were determined (exactly: differences between the values of raster map cells) at each level of generalization. The absolute differences obtained in each cell were related to the average number of population per area in the Bronowice district. Example: the 10\% value calculated in a given place, when calculating population density for the area 100x100m (1 ha) means that the actual population may differ by an average of 2.4 people (the population per hectare is for an average of 24 people for the Bronowice district). Thanks to such an approach, an easy-to-interpret measure was obtained. It is possible to trace the spatial distribution of errors. Averaged percentage errors (formula (1)) are a synthetic measure of the quality of the population mapping method in a given resolution (Fig. 6).
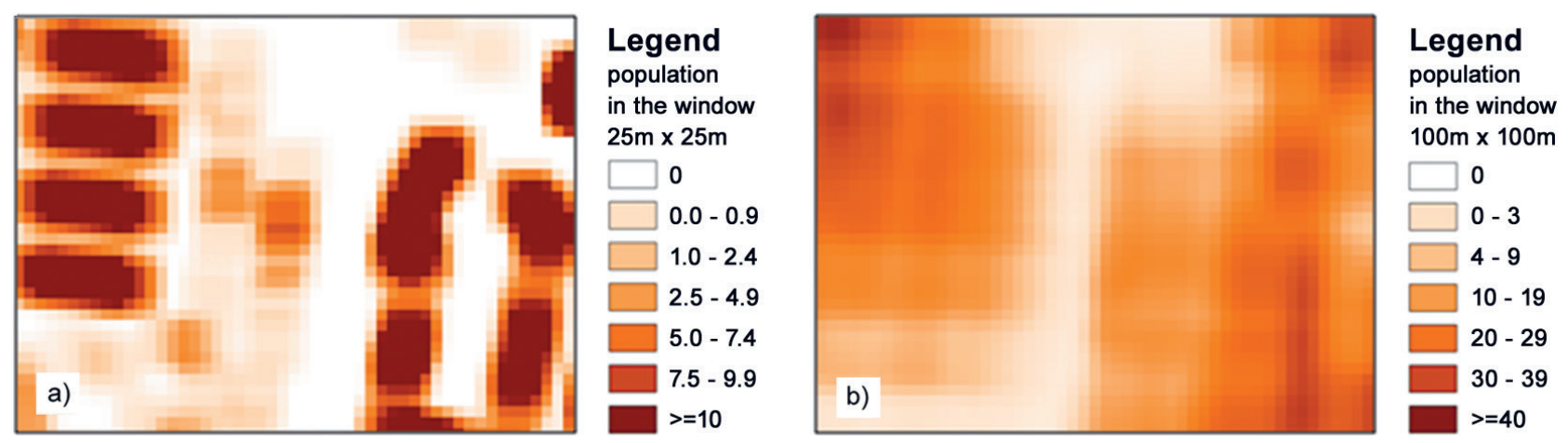

Fig. 4. Example of aggregation of population information from a reference map: a) calculation of the concentration in the window $25 \times 25 \mathrm{~m}$, b) calculation of the density in the window $100 \times 100 \mathrm{~m}$. Both raster maps in $5 \times 5 \mathrm{~m}$ resolution.

Rys. 4. Przykład degradacji informacji mapy referencyjnej: a) obliczenie zagęszczenia w otoczeniu $25 \times 25 \mathrm{~m}$, b) obliczenie zagęszczenia w otoczeniu $100 \times 100 \mathrm{~m}$. Mapy rastrowe $\mathrm{w}$ rozdzielczości $5 \times 5 \mathrm{~m}$ 


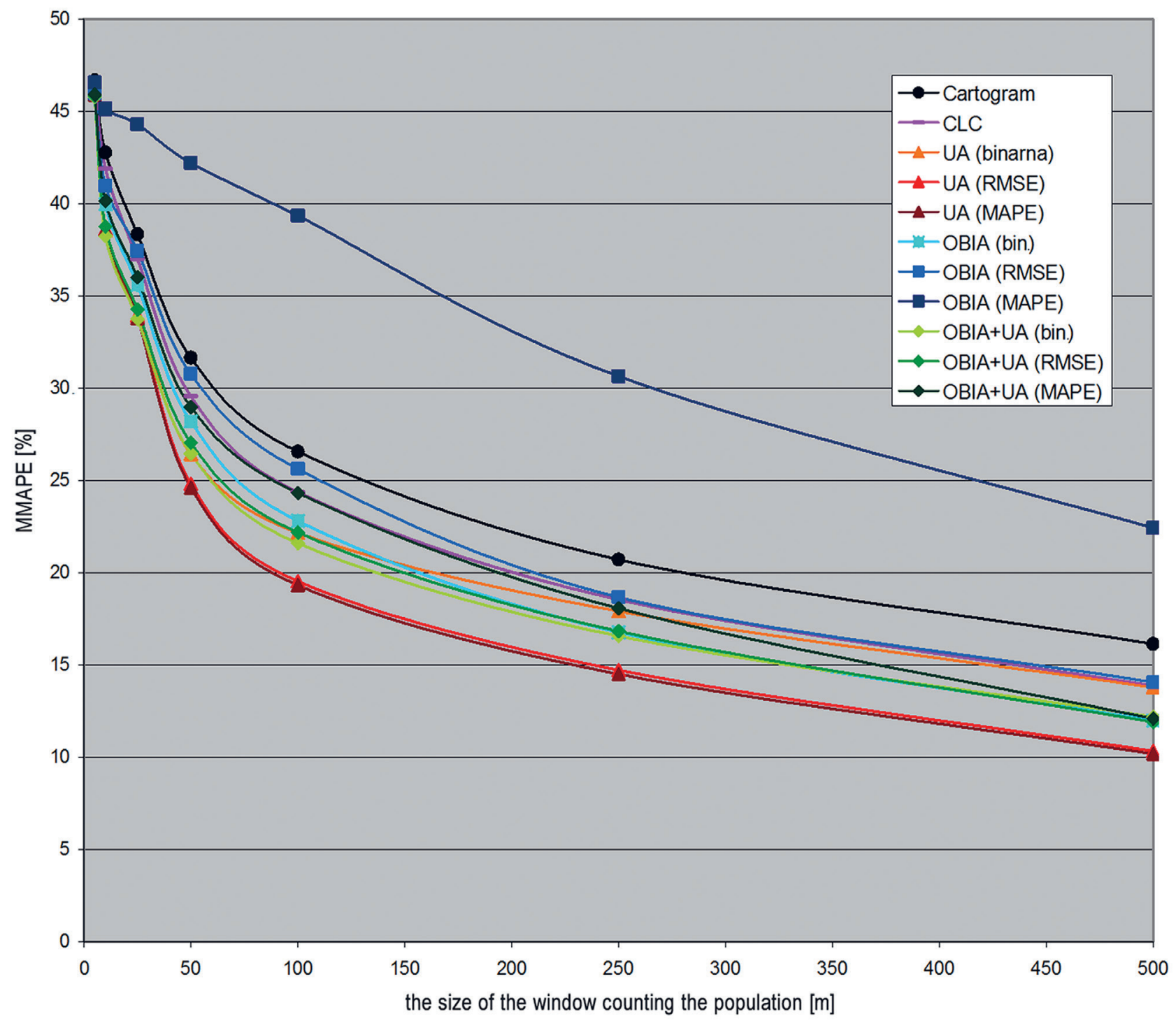

Fig. 5. Results of the analysis on the Bronowice test field - average percentage errors MMAPE [\%] of the population density map for the tested variants, depending on the level of their generalization

Rys. 5. Wyniki analizy na polu testowym Bronowice - średnie błędy procentowe MMAPE [\%] map zagęszczenia ludności dla testowanych wariantów, w zależności od poziomu ich generalizacji

$$
\operatorname{MMAPE}(d)_{\text {density }(r)}=100 \% \times \frac{\sum_{m} \sum_{n}\left|\operatorname{Pop}_{\text {density }(r)}(d)-\operatorname{Pop}_{\text {density }(r)}(r e f)\right|}{\sum_{i}\left(\operatorname{Pop}\left(j u_{i}\right)\right.}
$$

where:

$\operatorname{MMAPE}(d)_{\text {density }(r)}$ - modified mean absolute percentage error estimation of population density in resolution $r$;

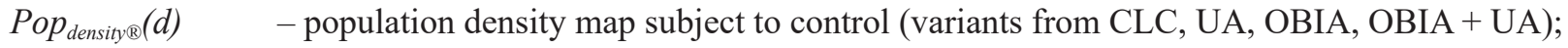

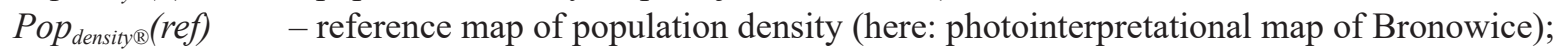

$\operatorname{Pop}\left(j u_{i}\right) \quad-$ the sum of the population from statistical data from u.u. of the analyzed area. 


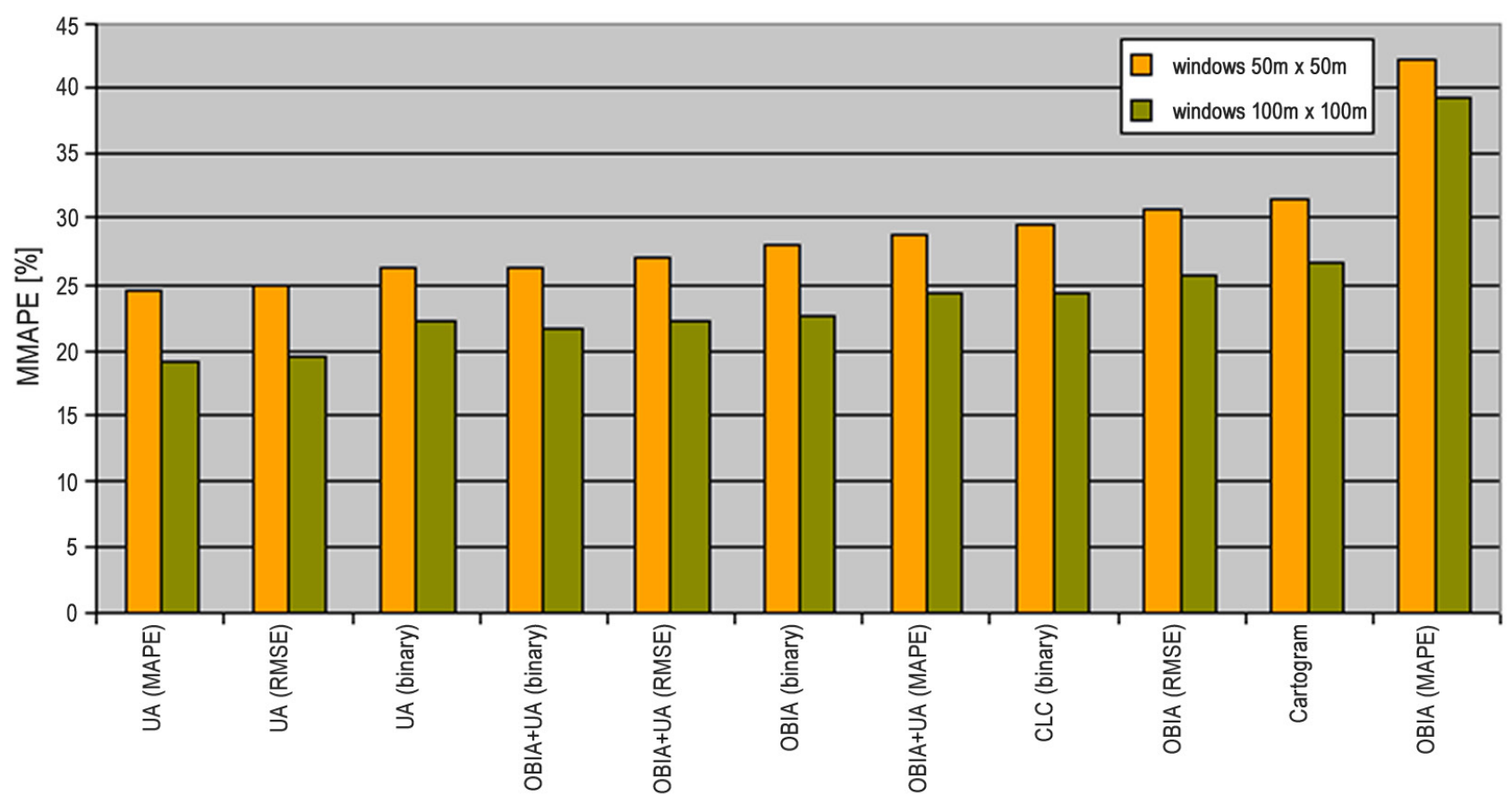

Fig. 6. Analysis results on the Bronowice test field: ranking of methods in $50 \mathrm{~m}$ and $100 \mathrm{~m}$ resolution, according to the MMAPE [\%].

Rys. 6. Wyniki analizy na polu testowym Bronowice: ranking metod w rozdzielczości 50 m i 100 m, wg wskaźnika MMAPE [\%].

The ordered methods according to the obtained value of MMAPE [\%] for the cell surroundings $50 \times 50 \mathrm{~m}$ and $100 \times 100 \mathrm{~m}$ are shown in Figure 6 .

\section{DISCUSSION}

The applied methodology of using the reference map of Bronowice confirmed that in the gradual generalization of maps the level of recorded errors drops (Fig. $5 \mathrm{a})$. In the highest resolution ( $5 \mathrm{~m}$ cell) for all variants, including simple cartogram, the level of errors is similar and amounts to over $45 \%$. The very small variation between the variants results from the fact that, at this scale of detail, none of the methods properly maps the population distribution. Gradual generalization allows to assess which limiting variables and variable relationships actually allow to better improve spatial differentiation of population in relation to simple cartogram. With a resolution of $10 \mathrm{~m}$ errors are around $38-42 \% \%$, for $25 \mathrm{~m} 33-37 \%$, for $50 \mathrm{~m} 24-30 \%$, for $100 \mathrm{~m} 19-24 \%$, for $250 \mathrm{~m} 21-19 \%$, for $500 \mathrm{~m} 10-14 \%$. In this respect, the results of all variants are included, with the excep- tion of the method based on OBIA with minimization of MAPE. As you can see, the largest decreases in the level of errors are noted in generalizations from $5 \mathrm{~m}$ to $50-100 \mathrm{~m}$ and the latter two resolutions should be considered as a compromise between the detail of population conversion and its reliability. The best results were obtained by UA-based surface-and-weight methods (Fig. 6), which in comparison to the simple cartogram gave about 2 times lower errors (in generalizations up to $100 \mathrm{~m}$, giving an accuracy of about $19 \%$ ). In the case of the OBIA (MAPE) method the equifinality phenomenon was detected. At the stage of calculating weights (relative densities of individual types of buildings) a statistical effect of low percentage errors in individual urban units was obtained (see the first article of the cycle). However, the reference to the detailed reference map of Bronowice showed that the spatial distribution of population developed is incorrect. For example, for the $100 \mathrm{~m}$ resolution, for the MMAPE straight cartogram it is $26.5 \%$, and after conversion with the variant OBIA MAPE, the value increases to $39.3 \%$, when for other population maps it drops to about $20 \%$. 


\section{CONCLUSIONS}

In total, in the first and second part of the publication cycle, 12 variants of Kraków's population maps were developed. In the third part, they were subjected to a detailed analysis based on an independent set of reference data.

The basic objective set for the Bronowice reference map was to exclude the equifinality phenomenon, which could have occurred in the validation of methods at the level of urban units (see first and second part of the publication cycle) and / or the CSO kilometer grid (see the fourth part of the cycle). That is, a situation in which there would be low deviations at this level of generalization, while within the mesh of the grid, the estimated population distribution would not be in line with reality. Analyzing the results (Fig. 5, Fig. 6) it is clearly visible that detailed mapping with the variant OBIA (MAPE) is not correct. Can this defect be captured on generalized data, based on CSO reference data? Research in this direction and discussion will be conducted in the next part of the cycle.

At this stage of validation, the best results among the tested variants were obtained for surface-by-weight methods based on UA data. The third place was taken by the UA binary map, the next - OBIA + UA. The introduction of these variants is the result of very bad OBIA results. Particularly in surface-by-weight methods, very high errors were reported, reported in the second part of the cycle. This resulted in the need to use UA data for the correction of the extent of building obtained from the object classification. Thanks to this treatment, industrial and commercial areas were removed from the building. The effect of improving the parameters was obtained in urban units (see the second part of the cycle), which also confirms the ranking from Figure 6 (in general, the OBIA + UA methods have lower MMAPE errors than the OBIA method). However, by reversing the situation, it can be said that OBIA + UA is population mapping based on Urban Atlas, where the internal variability of the UA category was attempted to be described in more detail by OBIA. This did not result, as the results are worse in relation to the UA. The use of object-oriented classification does not bring good results - only using the binary method one can obtain slightly better results than based on CLC. The conducted ranking of methods requires confrontation with validation, which is planned in the fourth part of the cycle, based on an independent CSO grid with data on the population.

\section{ACKNOWLEDGEMENTS}

The authors would like to thank Małgorzata Timek for carrying out the verification of the Bronowice test field, calculating the value of the MMAPE coefficient for the tested variants and developing Figures 3 and 4 .

\section{REFERENCES}

Bielecka E. (2005). A Dasymetric population density map of Poland. Materiały XXII Międzynarodowego Kongresu Kartograficznego, 11-16 lipca La Coruna, Hiszpania

Całka B., Bielecka E., Zdunkiewicz K. (2016). Redistribution population data across a regular spatial grid according to buildings characteristics, Geodesy and Cartography,| Vol. 65 , no. 2, pp. 149-162

Gallego F.J., Peedell S. (2001). Using CORINE Land Cover to map population density. Towards agri-environmental indicators. EEA Topic report 6/2001, 94-105

Kang J., Körner M., Wang Y., Taubenböck H., Zhu X.X. (2018). Building instance classification using street view images. ISPRS Journal of Photogrammetry and Remote Sensing, https://doi.org/10.1016/j.isprsjprs.2018.02.006

Kruszyńska A., Wendel I. (2001). Dzielnice Krakowa, Urząd Miasta Krakowa, Kancelaria Rady Miasta i Dzielnic Krakowa, Kraków, s. 42

Kunze C., Hecht R. (2015). Semantic enrichment of building data with volunteered geographic information to improve mappings of dwelling units and population, Computers Environment and Urban Systems, vol. 53, DOI: 10.1016/ j.compenvurbsys.2015.04.002

Maantay J.A., Maroko A.R., Herrmann Ch. (2007). Mapping Population Distribution in the Urban Environment: The Cadastral-based Expert Dasymetric System (CEDS). Cartography and Geographic Information Science

Nagle N.N., Buttenfield B.P., Leyk S., Speilman S. (2014). Dasymetric Modeling and Uncertainty, Ann Assoc Am Geogr. 2014 Jan 1; 104(1): 80-95. doi: 10.1080/00045608.2013.843439

Pavia J.M., Cantarino I. (2017). Dasymetric distribution of votes in a dense city, Applied Geography, 86, (22)

Pirowski T, Bartos K. (2018). Detailed mapping of the distribution of a city population based on information from the national database on buildings. Geodetski Vestnik; ISSN 0351-0271. - 2018 vol. 62 no. 3, DOI: 10.15292/geodetski-vestnik.2018.03.458-471;

Pirowski T., Drzewiecki W. (2012). Mapa gęstości zaludnienia Krakowa, propozycja metodyki opracowania oraz przykładowe zastosowania. Roczniki Geomatyki, T. 10, z. 3

Pirowski T., Timek M. (2018): Analysis of land use and land cover maps suitability for modeling population density of urban areas - redistribution to new spatial unit based on CLC and UA databases, Geoinformatica Polonica, 
ISSN 1642-2511. - 2018 vol. 17, s. 53-64, DOI 10.4467/ 21995923GP.18.004.9162

Pirowski T., Wietrzykowska K., Timek M. (2018): Analysis of land use and land cover maps suitability for modeling population density of urban areas - redistribution to new spatial unit based on the object classification of RapidEye data, Geoinformatica Polonica, ISSN 1642-2511. - 2018 vol. 17, s. 65-75, DOI 10.4467/21995923GP.18.004.9163

Ratajski R. (1989). Metodyka kartografii społeczno-gospodarczej. Warszawa-Wrocław: m. Państwowe Przedsiębiorstwo Wydawnictw Kartograficznych im. Eugeniusza Romera

Stofan, K. (2008). Estimating Pashtun sub-tribal populations in Mizan District, Zabul Province, Afghanistan using Quickbird satellite imagery and dasymetric mapping. Geographic Information Systems for the Geospatial Intelligence Professional Summer, Capstone Project

Tomás L., Fonseca L., Almeida C., Leonardi F., Pereira M. (2016). 3. Urban population estimation based on residential buildings volume using IKONOS-2 images and lidar data. International Journal of Remote Sensing, Volume 37, https:// doi.org/10.1080/01431161.2015.1121301

Wang L., Wu C. (2010). Population estimation using remote sensing and GIS technologies. International Journal of Remote Sensing. Volume 31, 2010 - Issue 21. https://doi.org/1 $0.1080 / 01431161.2010 .496809$

Wu, S.-S., Qiu, X. and Wang, L. (2005). Population Estimation Methods in GIS and Remote Sensing: a review. GIScience and Remote sensing, 42 (1):58-74; doi: 10.2747/1548$-1603.42 .1 .80$

Xie Z. (2006). A Framework for Interpolating the Population Surface at the Residential-Housing-Unit Level. GIScience \& Remote Sensing, vol. 43

Zandbergen, P., Ignizio, D. (2010). Comparison of dasymetric mapping techniques for small-area population estimates. Cartography and Geographic Information Science, 37 (3): 199-214. DOI:10.1559/152304010792194985 